\title{
园林绿化工程施工质量控制解析
}

刘佳吉 朱啊南

DOI:10.32629/eep.v2i7.355

[摘 要] 随着社会经济的快速发展, 国民生活水平与质量有了显著提升, 生态、绿色环境建设成为了社会各界关注的焦点, 这也 使得园林绿化提上日程。为了能够提高园林绿化效果,充分发挥园林绿化的作用与价值,就必须有效保证园林绿化施工质量。 基于此,本文在阐述园林绿化概念以及重要性的同时,通过分析园林绿化工程施工影响要素,重点研究了园林绿化施工质量控 制措施。

[关键词] 园林绿化; 施工质量; 控制措施

基于新时代背景下, 人们对生活有了更多的追求, 尤其 是生活环境。为了能够满足人们的生活需要, 园林绿化成为 了一种重要路径, 所以需要增加园林绿化建设投入, 促进城 市朝着绿色、低碳、生态方向发展。但是纵观我国园林绿化 施工效果, 在整体上并不是很理想, 由于过度的关注经济发 展, 轻视自然生态环境保护, 所以导致园林绿化未能达成预 期目标。为此, 在园林绿化施工中必须以实际情况为依据, 综合分析与研究各种施工影响要素, 然后制定科学、可行的 施工质量控制措施, 才能够切实保证园林绿化施工效果, 发 挥园林绿化的价值与作用, 为人们创造绿色家园。

\section{1 园林绿化概念}

园林绿化指的是风景园林绿地工程。实施园林绿化不仅 能够使人们与自然和谐相处, 为人们提供一个休息与娱乐场 所, 也能够进一步优化与改善自然生态环境, 实现城市经济 的可持续性发展 ${ }^{[1]}$ 。从本质上分析, 园林绿化涉及的范围十 分地广, 如园林筑山工程、园林铺地工程以及园林建筑工程 等。此外, 园林绿化施工也能够实现地面构筑物和园林景观 之间的完美契合, 将两者巧妙的融于一体。

\section{2 园林绿化施工质量控制的重要性}

园林绿化是城市建设发展中的一项关键内容, 其不但能 够提升城市魅力, 塑造良好的城市形象, 也能够为人们创造 绿色、低碳的生活环境。但是结合园林绿化实际情况, 因为 受到各种施工要素的影响, 园林绿化工程的整体施工效果并 不乐观, 甚至施工质量偏低 ${ }^{[2]}$ 。基于新时代背景下, 为了能够 进一步发挥园林绿化的功能与作用, 就必须加强园林绿化工 程施工质量控制。首先, 施工质量控制作为园林绿化施工管 理中的一项重要内容, 严格、有效的园林绿化施工质量控制, 可以切实提升园林绿化水平, 保证园林绿化施工效果, 充分 发挥园林绿化的功能, 深化城市魅力, 打造绿色、生态的城市 空间。其次, 从园林绿化施工企业方面分析, 科学、可行其次, 从园林绿化施工企业方面分析, 合理、有效的施工质量控制能 够实现园林绿化工程的标准化与规范化, 实现造价的最优化, 为施工企业创造更多的经济利益与社会效益。最后, 有效的施 工质量控制能够进一步提升园林绿化工程质量, 在改善与优 化生态环境的同时, 也使人们的生活品质有了明显提升。

\section{3 园林绿化工程施工质量影响要素分析}

3. 1施工准备阶段的影响

园林绿化工程的设计阶段, 若是没有开展实地考察, 就 无法准确、真实的掌握园林绿化工程施工场地基本情况, 而 仅仅是参考相应部门绘制的简图或是卫星地图, 或是从网络 中整理的资料信息, 尽管在思想上高度重视园林绿化工程图 纸设计工作, 可是仍然会与现实情况有偏差, 例如园林绿化 工程的上空可能有高压线路, 若是在设计图纸时选择了高大 乔木, 显然是难以实现的 ${ }^{[3]}$ 。园林绿化工程施工之前, 施工企业 未与设计工作人员展开沟通, 很难准确理解图纸设计的真正 意图, 从而就难以实现各项资源的科学配置, 严重影响园林绿 化施工进度, 甚至也会对园林绿化施工质量带来负面影响。

\section{2 施工队伍的影响}

目前, 我国园林绿化工程施工管理仍然存在着滞后性, 尤其是施工队伍的专业技术能力与综合素养偏低, 从而对园 林绿化工程的施工质量造成负面影响。随着我国园林行业的 快速发展, 施工队伍的规模与数量也明显增大, 然而施工技 术工作人员的专业能力与综合素养却没有什么本质上改变, 施工队伍中大多数人是农民工, 他们实践经验不足, 而且也 没有参与过培训活动, 对于图纸的设计意图难以准确理解, 从而就很容易引发施工质量问题。此外, 园林绿化工程施工 管理工作人员缺少专业能力, 难以有效组织施工人员展开施 工, 从而就会影响施工进度, 甚至还会发生返工问题。

\section{3施工过程的影响}

从本质上分析, 园林绿化工程涉及的范围比较广, 所以 施工质量影响要素也很多, 比如水文条件、气候条件等, 而且 园林绿化工程施工还存在着季节性特点, 在进行施工时还有 可能会碰见地下管网或者是地上建筑物, 由此有关部门必须 通力协作, 如果其中任何一个环节发生问题, 就可能会影响 园林绿化工程的施工质量 ${ }^{[4]}$ 。目前, 有的施工企业为了能够 提前实地面绿化, 一般情况下施工顺序是先种植绿色植物, 然后进行土建与地下管网施工, 由此就会严重损坏植被, 不 但在一定程度上增加了工作量与造价, 也严重影响了施工 质量。

3. 4后期养护的影响 
园林绿化管理体系的差异性, 导致园林绿化工程普遍存 在着 “重种植、轻管理” 的现象, 所以无法有效保证园林绿 化工程施工质量。事实上, 后期养护也关系着园林绿化工程 施工质量。然而纵观园林绿化养护实际情况, 工作人员的责 任心与专业能力相对偏低, 在养护时很难做到位, 从而严重 影响绿植成活率, 也不利于提高园林绿化整体美观性。

\section{4 园林绿化施工质量控制有效措施}

4. 1 园林绿化总目标的有效控制

园林绿化的总目标是绿色环境、优质空气、生态和谐、 宜人生活, 追求的是自然生态环境与城市景观之间的有机融 合。基于此, 必须对自然生态环境有着深刻认知, 科学进行园 林绿化生态性规划, 根据现代设计理念展开差异化设计与施 工, 充分发挥历史文化底蕴与特色, 具有独特的设计思想与 思路。

4. 2 严格管理施工队伍

从园林绿化工程方面进行分析, 有关监管部门必须加大 施工质量监督力度, 而且施工企业在进行施工之前也要制定 行之有效的质量保证体系、施工质量管理机制, 安排专业工 作人员科学指导与组织施工技术人员完成施工; 安排实践经 验深厚的园林绿化工程项目经理负责施工, 同时也要兼具领 导才能与管理能力, 有强烈责任心, 从而组织与要求施工人 员进行高标准、高质量施工; 安排专业化的技术人员负责进 场指导, 不仅要了解植物种植规律与特点, 有效把握园林绿 化工程施工技术要点, 还要具备独特的眼界, 扎实的技能实 现园林绿化施工科学、有效指导。此外, 人才是园林绿化工 程施工质量的重要影响要素, 所以针对施工技术人员要组织 其参与专业技能培训与教育活动, 不断地提高其专业能力与 综合素养, 从而为保证园林绿化工程整体施工质量创造有利 条件。

4. 3加大施工过程管理力度

在园林绿化工程施工之前, 各个参建方必须对图纸展开 严格会审, 及时了解、有效把握图纸设计具体内容, 同时针对 图纸中的问题展开深入探讨, 然后及时的修正, 以切实保证 园林绿化工程后续施工的正常推进 ${ }^{[5]}$ 。关于绿植的采购, 要 尽量的以当地植物为主, 同时提前进行断根假植, 使其经过 一段假植时间之后方可移植, 从而提升绿植成活率。针对园 林绿化工程的施工过程进行全方面管理, 加大施工各个环节
质量的控制力度, 深化细节处理, 针对植物的种植需要进行 科学安排与规划, 确保园林绿化施工总体质量的基础上, 追 求人类与自然生态环境的协调发展。

4. 4加强施工质量监督

为了能够实现园林绿化工程的正常施工, 必须要对施工 所有环节展开全面性监控, 严格根据图纸设计等有关要求展 开施工, 安排园林绿化专业技术人员负责到场监督与指导施 工, 而且项目经理与有关部门必须协同对施工质量进行严格 监管。为了能够全方面深化园林绿化工程的总体施工质量, 就需要对当地自然气候、地质条件等展开综合性分析, 认真 研究各个细节, 从而才能够实现园林绿化的真正目标。

\section{5 高度重视园林绿化后期养护}

园林绿化施工企业在施工与养护过程之中, 必须严格遵 守园林绿化施工规定与养护规范要求, 提高园林绿化养护工 作的规范性与有效性。此外, 选择科学、合理的形式展开园 林绿化养护工作, 提升植物种植成活率。园林绿化相关部门 需要建立科学、有效的养护策略, 当园林绿化工程施工结束 之后, 严格按照标准要求完成园林绿化养护工作, 同时结合 具体情况对园林绿化养护展开详细记录, 不断地优化与完善 园林绿化养护体系。

\section{5 结束语}

园林绿化是城市建设发展中的一项重要内容, 其不仅能 够美化城市形象, 也能够为人们创造绿色、健康的生活环境。 所以在园林绿化工程施工时, 必须综合分析各项施工影响要 素, 然后制定科学、可行的施工质量控制措施, 有效保证园林 绿化施工整体质量, 从而有效发挥园林绿化的作用与价值。

\section{[参考文献]}

[1]冯会敏,易文增.基于市政园林绿化工程施工技术及 质量控制探讨[J].科技展望,2015,25(28):58.

[2]彭志红.园林绿化工程施工质量控制要点一泰安市惠丰 园小区园林绿化工程调查分析[J].林业科技,2018,43(4):44-46.

[3]张晓敏,相龙琴.影响园林绿化工程质量常见问题分 析及改进措施[J].城市建设理论研究(电子版),2017,(31):205.

[4]何丽昆.试论园林绿化工程施工质量控制途径及思路 [J].价值工程,2018,37(03):172-173.

[5]武艺.试论园林绿化工程施工质量控制途径及思路 [J].现代园艺,2018,(22):194. 